\title{
PENGARUH PELAKSANAAN MAINTENANCE DAN LINGKUNGAN FISIK TERHADAP KEPUASAN PENGGUNA JASA GHADA GYM DAN FITNESS CENTER DI DENPASAR
}

\author{
Agus Suarjaya ${ }^{1}$, Putu Gede Denny Herlambang ${ }^{2}$ \\ 1,2Fakultas Ekonomi Universitas Ngurah Rai, Bali, Indonesia \\ e-mail: regesajus954@gmail.com
}

\begin{abstract}
Abstrak: Jumlah responden dalam penelitian ini sebanyak 70 menggunakan teknik sampling insidental. Berdasarkan hasil analisis data, uji signifikansi simultan (F-test) dapat menunjukkan bahwa pelaksanaan maintenance dan lingkungan fisik secara simultan berpengaruh positif dan signifikan terhadap kepuasan pengguna jasa dan uji signifikansi parsial (t-test) menunjukkan bahwa pelaksanaan maintenance secara parsial berpengaruh positif dan signifikan terhadap kepuasan pengguna jasa, lingkungan fisik secara parsial berpengaruh positif dan signifikan terhadap kepuasan pengguna jasa.
\end{abstract}

Kata kunci: Kepuasan Pelanggan, Maintenance, dan Lingkungan Fisik

Abstract: The number of respondents in this study was 70 using incidental sampling techniques. The simultaneous significance test (F-test) show that maintenance and physical environment simultaneously has a positive and significant effect on service user satisfaction and the partial significance test (t-test) shows that maintenance partially positive and significant effect on service user satisfaction on Ghada Gym and Fitness Center, the physical environment partially has a positive and significant effect on service user satisfaction.

Keywords: Customer Satisfaction, Maintenance, Physical Environemnt

\section{PENDAHULUAN}

Seiring bertambahnya usia dan semakin bertambah padatnya aktifitas yang dijalani seseorang, semakin menurun pula tingkat kesadaran seseorang akan pentingnya berolahraga sebagai kebutuhan sehari-hari bagi kesehatan tubuhnya. Walau dengan uang yang banyak dapat membeli segalanya, tetapi kunci kebahagiaan yang paling penting adalah kesehatan. Memiliki bentuk yang proposional dan ideal seperti yang dimiliki oleh para selebriti dunia adalah dambaan setiap individu. Belakangan ini semakin banyak orang yang ingin berolahraga di pusat kebugaran (Fitness) agar mendapatkan tubuh yang di idamkan. Hal ini ditangkap oleh berbagai pusat kebugaran sebagai peluang untuk lebih memperkenalkan Fitness kepada masyarakat.

Fitness center menyediakan pelatih (Terainer) Yang telah berpengalaman dan ahli dalam bidangnya untuk membantu menentukan program latihan sesuai kebutuhan konsumen terutama dimaksudkan untuk membantu konsumen awam yang baru pertama kali berolahraga di pusat kebugaran. Kini Fitness center menjadi kian populer bahkan sudah menjadi gayahidup dikalangan masyarakat yang telah menyadari pentingnya berolahraga, tak terkecuali para wanita dan remaja. Selain aktivitas olahraga permainan, latihan olahraga juga dapat dilakukan dengan menggunakan latihan beban. 
Ghada Gym fitness center sebagai tempat penelitia berpusat di Denpasardalam perkembangan usahanya, pada tahun 2018 Ghada Gym dan Fitness Center mengalami penurunan jumlah kunjungan member. Berdasarkan wawancara dengan pengguna jasa Ghada Gym terdapat beberapa permasalahan antara lain parkir yang kurang luas, sirkulasi udara kurang memadai, toilet yang berbau tak sedap, alat alat fitness yang kurang lengkap. Banyaknya alat alat fitness yang ada di Gada Gym adalah 18 jenis alat fitness Untuk perawatan alat alat fitness Ghada Gym dilakukan satu jam sebelum tutup, yang dilakukan maintenance dalam perawatan alat di Ghada Gym memakai minyak singer dan mengelap alat fitness.

Berdasarkan wawancara dengan member Ghada Gym bahwa di fitnes Ghada Gym mengeluh tentang kamar mandi berbau tidak sedap, tidak boleh fitnes bawa mobil, loker kebanyakan tidak bisa dipakai dan ada beberapa alat yang terasa berat seperti cable crossover, butterfly machine, kenee rise dengan timbulnya permasalahan di atas maka pihak Ghada Gym melakukan evaluasi kembali untuk memberikan pelayanan yang semaksimal mungkin agar para member bisa merasa puas dan nyaman untuk berolah raga di Ghada Gym fitnes center.Berdasarkan pernyataan diatas maka penulis tertarik untuk melakukan penelitian dengan topik Pengaruh Pelaksanaan maintenance dan lingkungan fisik terhadap pengguna jasa fitnes Ghada Gym di Denpasar.

Dalam penelitian ini, faktor-faktor yang diduga peneliti dapat mempengaruhi seseorang dalam memilih fitness center sebagai tempat untuk melatih kebugaran tubuh diantaranya ialah motivasi, lokasi, dan lingkungan fisik atau kualitas jasa. Menurut (Rakhmat, 2016), motivasi adalah sebuah proses untuk tercapainya suatu tujuan. Seseorang yang mempunyai motivasi berarti ia telah mempunyai kekuatan untuk memperoleh kesuksesan dalam kehidupan.

Menurut (Tjiptono \& Chandra, 2005) mendefinisikan lingkungan fisik/kualitas jasa sebagai ukuran seberapa bagus tingkat layanan yang diberikan mampu sesuai dengan ekspektasi Pengguna jasa (dalam Kualitas jasa adalah sejauh mana jasa memenuhi spesifikasi-spesifikasinya.

Kualitas yang diinterpretasikan ISO 9000 merupakan perpaduan antara sifat dankarakteristik yang menentukan sejauh mana keluaran dapat memenuhi persyaratan kebutuhan Pengguna jasa.

Disamping motivasi member, dalam mendirikan perusahaan pemilihan lokasi harus sangat dipertimbangkan. Lokasi yang strategis dan mudah diketahui calon konsumen dapat menentukan keberhasilan suatu usaha. Dalam (Yuliani, 2005), Manullang mengatakan bahwa lokasi atau tempat atau letak adalah tempat di mana perusahaan itu didirikan. Ghada gym berada di lokasi yang cukup strategis yaitu dekat dengan lembaga pendidikan, bank, pangkalan angkatan darat, dan pemukiman. Para pengusaha harus pintar memilih lokasi yang

strategisagardapatmenarikbanyakkonsumentapitidakmengganggumasyarakatse kitar.

Berdasarkan pemaparan teori dan permasalah yang terjadi dalam perusahaan, maka peneliti tertarik untuk meneliti lebih jauh lagi mengenai pengaruh maintenance dan lingkungan fisik terhadap kepuasan pengguna jasa dengan judul "Pengaruh Pelaksanaan Maintenance dan Lingkungan Fisik terhadap Kepuasan Pengguna jasa Ghada Gym dan Fitness Center di Denpasar".

\section{Jurnal Manajemen dan Bisnis Equlibrium}

DOI: https://doi.org/10.47329/jurnal_mbe.v6i1.425 


\section{METODE PENELITIAN}

Berdasarkan permasalahan yang diteliti, penelitian ini digolongkan pada penelitian asosiatif, yaitu suatu penelitian yang bertujuan untuk mengetahui pengaruh sebab akibat dari variabel yang diteliti. Penelitian ini bertujuan untuk mencari tahu pengaruh dari pelaksanaan maintenance dan lingkungan fisik terhadap kepuasan pengguna jasa pada Ghada Gym dan Fitness Center di Denpasar.

Populasi adalah wilayah generalisasi yang terdiri atas objek atau subjek yang mempunyai kualitas dan karakteristik tertentu yang ditetapkan oleh peneliti untuk dipelajari dan kemudian ditarik kesimpulannya (Sugiyono, 2016:80). Populasi dalam penelitian ini adalah populasi yang dimaksud adalah banyaknya member di Ghada Gym dan Fitness Center adalah 200 orang pada tahun 2018.

Sampel adalah bagian dari jumlah dan karakteristik yang dimiliki oleh populasi tersebut (Noeraini \& Sugiyono, 2016) Teknik sampling yang digunakan adalah teknik sampling insidental, yaitu Dimana sampel ditentukan berdasarkan kebetulan, yaitu siapa saja yang secara kebetulan/insidental bertemu dengan peneliti dapat digunakan sebagai sampel, bila dipandang orang yang kebetulan ditemui cocok sebagai sumber data (Sugiyono, 2017).

Berdasarkan perhitungan maka jumlah responden yang dijadikan sampel penelitian ini adalah sebanyak 70 orang. Teknik pengumpulan data dalam penelitian ini dilakukan dengan observasi, wawancara, studi dokumentasi dan kuesioner.

Teknik analisis data dalam penelitian ini menggunakan pendekatan kuantitatif yaitu analisis statistik inferensial, terdiri dari: uji asumsi klasik yaitu uji multikolinearitas, uji normalitas dan uji heteroskedastisitas, analisis regresi linier berganda, analisis korelasi berganda, analisis determinasi, uji signifikansi parsial (t-test) dan uji signifikansi simultan (F-test).

\section{HASIL PENELITIAN}

a. Uji Asumsi Klasik

1. Uji multikolinearitas

Hasil uji multikolinearitas dapat dilihat pada Tabel 1 berikut.

Tabel 1

Collinearity Statistic

\begin{tabular}{ccc}
\hline \multirow{2}{*}{ Variabel Bebas } & \multicolumn{2}{c}{$\begin{array}{c}\text { Collinearity } \\
\text { Statistic }\end{array}$} \\
\cline { 2 - 3 } & $\begin{array}{c}\text { Toleran } \\
\boldsymbol{c e}\end{array}$ & VIF \\
\hline $\begin{array}{c}\text { Pelaksanaan } \\
\text { maintenance }\left(\mathrm{X}_{1}\right)\end{array}$ & 0,991 & 1,009 \\
\hline Lingkungan fisik $\left(\mathrm{X}_{2}\right)$ & 0,991 & 1,009 \\
\hline Sumber : Olah data SPSS 25.0 for Windows, 2019
\end{tabular}

Pada Tabel 1 dapat dilihat bahwa hasil perhitungan menunjukkan tidak ada variabel bebas yang memiliki nilai Tolerance yang kurang dari 0,10 yang berati tidak ada kolerasi antara variabel bebas yang nilainya lebih dari $95 \%$, nilai Variance Inflation Factor (VIF) juga menunjukkan hal yang sama, yaitu tidak ada variabel bebas yang memiliki nilai diatas 10, sehingga tidak terjadi multikolinearitas dalam model regresi. 


\section{Uji Normalitas}

Hasil uji normalitas dapat dilihat pada Tabel 2 berikut

Tabel 2

Hasil Uji Kolmogorov-Smirnov (K-S)

Unstandardized

\begin{tabular}{cc} 
& Residual \\
\hline $\mathrm{N}$ & 70 \\
\hline Test & .068 \\
Statistic & \\
\hline $\begin{array}{c}\text { Asymp. } \\
\text { Sig. }\end{array}$ & $.200^{\mathrm{c}, \mathrm{d}}$ \\
\end{tabular}

(2-tailed)

Sumber: Olah data SPSS 25.0 for Windows, 2019

Pada Tabel 2 dapat dilihat bahwa hasil perhitungan Asymp. Sig. (2-tailed) menunjukkan nilai sebesar 0,200 lebih dibandingkan dengan 0,05, sehingga dapat dikatakan variabel penelitian yang digunakan tersebut terdistribusi secara normal, sehingga persamaan regresi dapat digunakan dalam penelitian.

\section{Uji Heteroskedastisitas}

Hasil uji heteroskedastisitas dapat dilihat pada Tabel 3 berikut.

Tabel 3

\section{Hasil Perhitungan Uji Glesjer}

\begin{tabular}{ccc} 
Model & $\mathbf{t}$ & Sig. \\
\hline (Constant) & 1,736 & 0,087 \\
\hline $\begin{array}{c}\text { Pelaksanaan } \\
\text { maintenance }\end{array}$ & 0,396 & 0,694 \\
\hline Lingkungan fisik & $-1,123$ & 0,265 \\
\hline
\end{tabular}

a. Dependent Variable: res_2

Sumber: Olah data SPSS 25.0 for Windows, 2019

Pada Tabel 3 dapat dilihat bahwa seluruh nilai signifikan pada t-hitung variabel memiliki nilai lebih dari 0,05 , sehingga variabel penelitian yang digunakan tersebut bebas dari asumsi heteroskedastisitas.

\section{Persamaan Regresi Linier Berganda}

Hasil uji analisis regresi linier berganda dapat dilihat pada Tabel 4 berikut.

Tabel 4

Hasil Analisis Regresi Linier Berganda

\begin{tabular}{ccc}
\hline \multirow{2}{*}{ Model } & \multicolumn{2}{c}{$\begin{array}{c}\text { Unstandardized } \\
\text { Coefficients }\end{array}$} \\
\cline { 2 - 3 } B & Std. Error \\
\hline (Constant) & 9,473 & 2,733 \\
\hline
\end{tabular}




\begin{tabular}{ccc}
\hline & \multicolumn{2}{c}{$\begin{array}{c}\text { Unstandardized } \\
\text { Coefficients }\end{array}$} \\
\cline { 2 - 3 } Model & B & Std. Error \\
\hline $\begin{array}{l}\text { Pelaksanaan } \\
\text { maintenance }\end{array}$ & 0,458 & 0,125 \\
\hline Lingkungan fisik & 0,282 & 0,098 \\
\hline
\end{tabular}

a. Dependent Variable: Kepuasan pengguna jasaSumber : Olah data SPSS 25.0 for Windows, 2019

Hasil analisis regresi pada Tabel 4 di atas dapat disusun persamaan regresi sebagai berikut: $Y=9,473+0,458 X_{1}+0,282 X_{2}$. Dari persamaan regresi diatas dapat dijelaskan bahwa ada pengaruh yang positif secara simultan antara pelaksanaan maintenance dan lingkungan fisik terhadap kepuasan pengguna jasa.

Koefisien regresi bertanda positif berarti ada pengaruh yang searah, dimana jika pelaksanaan maintenancedan lingkungan fisik ditingkatkan maka akan diikuti oleh meningkatnya kepuasan pengguna jasa pada Ghada Gym dan Fitness Center di Denpasar.

\section{Analisis Kolerasi Berganda}

Hasil analisis kolerasi berganda dapat dilihat pada Tabel 5 berikut.

Tabel 5

Kolerasi Berganda dalam Model Summary

\begin{tabular}{cccc}
\hline \multicolumn{4}{c}{ Model Summary $^{b}$} \\
\hline $\mathrm{R}$ & R Square & $\begin{array}{c}\text { Adjusted } R \\
\text { Square }\end{array}$ & SEE \\
\hline $.777 \mathrm{a}$ & .772 & .205 & 2.44054 \\
\hline
\end{tabular}

Sumber: Olah data SPSS 25.0 for Windows, 2019

Berdasarkan Tabel 5, dapat dilihat nilai $\mathrm{R}=0,777$ berada antara 0,60 - 0,799 (korelasi tinggi) berarti ada hubungan yang positif dan tinggi secara simultan antara pelaksanaan maintenance dan lingkungan fisik terhadap kepuasan pengguna jasa pada Ghada Gym dan Fitness Center. Hubungan positif menunjukkan adanya hubungan searah, artinya apabila secara simultan meningkatnya pelaksanaan maintenance dan lingkungan fisik maka akan diikuti oleh meningkatnya kepuasan pengguna jasa.

\section{Koefisien Determinasi (Adjusted R Square)}

Berdasarkan Tabel 5 diketahui nilai $\mathrm{R}_{2}$ pada model summary adalah 0,772, sehingga didapat koefisien determinasi sebesar 77,2\%, artinya pengaruh pelaksanaan maintenance dan lingkungan fisik secara simultan terhadap kepuasan pengguna jasa adalah sebesar $77,2 \%$. Sisanya sebesar $100 \%-77,2 \%=22,8 \%$ dipengaruhi oleh faktor lain yang tidak diteliti dalam penelitian ini. 


\section{Uji Statistik F (F-test)}

Hasil uji hipotesis $\mathrm{F}$ dapat dilihat pada Tabel 6 berikut.

\section{Tabel 6}

\begin{tabular}{|c|c|c|c|}
\hline & Model & $\mathbf{F}$ & Sig. \\
\hline \multirow[t]{2}{*}{1} & Regression & 9,889 & $.000^{\mathrm{b}}$ \\
\hline & Residual & & \\
\hline
\end{tabular}

Sumber : Olah data SPSS 25.0 for Windows, 2019

Berdasarkan hasil uji $\mathrm{F}$ diperoleh F-hitung $=9,889$ dibandingkan dengan nilai F-tabel $=3,13$, maka nilai F-hitung lebih besar dari nilai F-tabel, dan F-hitung berada pada daerah penolakan Ho dengan sig. 0,000 lebih kecil dari 0,05. Oleh karena itu, Ho ditolak dan $\mathrm{H}_{\mathrm{a}}$ diterima.

Ini berarti bahwa pada tarafa $=5 \%$ secara simultan atau bersama-sama pelaksanaan maintenance dan lingkungan fisik memiliki pengaruhpositif dan signifikan (nyata) terhadap kepuasan pengguna jasa pada Ghada Gymdan Fitness Center, sehingga hipotesis yang berbunyi "Pelaksanaan maintenance dan lingkungan fisik secara simultan berpengaruh positif dan siginifikan terhadap Kepuasan pengguna jasa pada Ghada Gym dan Fitness Center" teruji kebenarannya atau Ho ditolak.

\section{Uji Statistik $\mathbf{t}$ (t-test)}

Hasil uji hipotesis $t$ dapat dilihat pada Tabel 7 berikut.

Tabel 7

Hasil Uji Statistik $\mathbf{t}(\mathrm{t}$-test)

\begin{tabular}{ccc}
\hline Model & $\mathbf{t}$ & Sig. \\
\hline (Constant) & 3,466 & 0,001 \\
\hline Pelaksanaan maintenance & 3,652 & 0,001 \\
\hline Lingkungan fisik & 2,871 & 0,005 \\
\hline 'Sumber : Olah data SPSS & 25.0 for Windows, & 2019
\end{tabular}

a. Pelaksanaan maintenance $\left(\mathrm{X}_{1}\right)$

Dari hasil uji $\mathrm{t}$ dapat dijelaskan bahwa, nilai t-hitung $=3,652$ lebih besar dibandingkan dengan nilai t-tabel $=1,668$ dan t-hitung berada pada daerah penolakan Ho, dengan nilai Sig. $=0,001$ kurang dari 0,05 sehingga Ho ditolak dan $\mathrm{H}_{\mathrm{a}}$ diterima.

Hal ini membuktikan jika Lingkungan fisik $\left(\mathrm{X}_{2}\right)$ dalam keadaan konstan, secara statistika pada taraf kepercayaan 5\%, maka pelaksanaan maintenance berpengaruhsignifikan atau nyata terhadap kepuasan pengguna jasa pada Ghada Gym dan Fitness Center sehingga hipotesis yang berbunyi "Pelaksanaan maintenance berpengaruh positif dan signifikan terhadap Kepuasan pengguna jasa pada Ghada Gym dan Fitness Center" adalah teruji kebenarannya atau Ho ditolak. 
b. Lingkungan fisik $\left(\mathrm{X}_{2}\right)$

Dari hasil uji $\mathrm{t}$ dijelaskan bahwa, nilai t-hitung $=2,871$ lebih besar dibandingkan dengan nilai t-tabel $=1,668$, dan $\mathrm{t}$-hitung berada pada daerah penolakan Ho, dengan nilai Sig. $=0,005$ kurang dari 0,05 sehingga Ho ditolak dan Ha diterima. Hal ini membuktikan jika pelaksanaan maintenance dalam keadaan konstan, secara statistika pada taraf kepercayaan 5\%, maka lingkungan fisik berpengaruh signifikan atau nyata terhadap kepuasan pengguna jasa sehingga hipotesis yang berbunyi "Lingkungan fisik berpengaruh positif dan signifikan terhadap Kepuasan pengguna jasa pada Ghada Gym dan Fitness Center" adalah teruji kebenarannya atau Ho ditolak

\section{KESIMPULAN}

Berdasarkan hasil analisis data dan pembahasan, maka dapat ditarik kesimpulan mengenai pengaruh pelaksanaan maintenance dan lingkungan fisik terhadap kepuasan pengguna jasa pada Ghada Gym dan Fitness Center sebagai berikut :

1. Pelaksanaan maintenance dan lingkungan fisik secara simultan berpengaruh positif dan signifikan terhadap kepuasan pengguna jasa pada Ghada Gym dan Fitness Center

2. Pelaksanaan maintenance secara parsial berpengaruh positif dan signifikan terhadap kepuasan pengguna jasa pada Ghada Gym dan Fitness Center

3. Lingkungan fisik secara parsial berpengaruh positif dan signifikan terhadap kepuasan pengguna jasa pada Ghada Gym dan Fitness Center

\section{SARAN}

Berdasarkan kesimpulan yang diperoleh dari hasil penelitian, maka dapat disampaikan beberapa saran yang berhubungan dengan pelaksanaan maintenance dan lingkungan fisik pada Ghada Gym dan Fitness Center guna meningkatkan kepuasan pengguna jasa adalah sebagai berikut :

1. Bagi Perusahaan

Sebaiknya perusahaan meningkatkan lagi intensitas pelaksanaan maintenance pada peralatan gym seperti membersihkan secara teratur peralatan olahraga. Untuk pegangan alat yang terbuat dari spon bisa dibersihkan dengan menggunakan alkohol agar bau, kotoran serta keringat yang menempel bisa hilang. Untuk daerah persendian alat dimana terjadi pergesekan yang bisa menyebabkan aus harus secara rutin diberikan pelumas. Untuk peralatan olahraga yang menggunakan tenaga listrik, ada perawatan tambahan yang harus dilakukan seperti mengecek kabel dan memastikan tidak ada yang putus maupun kendor. Setidaknya perusahaan melakukan pembaruan alat setahun sekali sehingga dapat digunakan dengan baik oleh para pengguna jasa dan mengurangi resiko yang tidak diinginkan seperti kecelakaan pada saat menggunakan alat, peralatan cepat rusak dan menimbulkan kerugian-kerugian lain yang tidak diinginkan, serta meningkatkan kembali kebersihan lingkungan fisik disekitar gym terutama pada bagian kamar mandi serta tempat latihan agar pengguna jasa merasa nyaman berada dalam ruangan gym dan menghimbau pengguna jasa untuk ikut menjaga kebersihan dan keamanan lingkungan gym.

2. Bagi Peneliti Selanjutnya

Dalam penelitian ini, variabel pelaksanaan maintenance dan lingkungan fisik mampu menjelaskan lebih banyak pengaruhnya terhadap kepuasan pengguna jasa sedangkan sedikit yang dipengaruhi oleh faktor lain yang tidak diteliti dalam penelitian ini, sehingga diharapkan bagi peneliti selanjutnya dapat meneliti faktor lain yang dapat 
mempengaruhi kepuasan pengguna jasa selain melalui kedua hal tersebut serta mengembangkan lagi teori-teori yang ada sehingga mendapatkan hasil penelitian yang lebih baik.

\section{UCAPAN TERIMAKASIH}

Ucapan terima kasih penulis sampaikan kepada seluruh narasumber yang bersedia membantu dan memberikan informasi yang diperlukan pada penelitian ini. Ucapan terima kasih juga kami sampaikan kepada para pihak yang membantu dalam selesainya tulisan ini.

\section{REFERENSI}

Agung, Gusti, Rai. 2008. Audit Kinerja Pada Sektor Publik: Konsep Praktik Studi Kasus. Penerbit: Salemba Empat.

Alma, (2016), Manajemen Pemasaran \& Pemasaran Jasa, Bandung: Alfabeta

Armstrong, Thomas. 1999. Kinds of Smart: Identifying and Developing Your Intelligences

Armstrong. 2002. 7 Kind Of Smart (Menemukan dan Meningkatkan Kecerdasan Anda berdasarka Teori Multiple Intelegence. Jakarta: Gramedia Pustaka Utama

Arimawati, Dyah Suci. 2015. Pemeliharaan Sarana dan Prasanrana Kantor di Balai Pengembangan Kegiatan Belajar (BPKB) Daerah Istimewa Yogyakarta. Thesis. Pendidikan Administrasi Perkantoran.

Boenawan, Kelvin Cahya. 2017. Pengaruh Kualitas Pelayanan Helios Fitness Di Jalan Peta No.241 Bandung terhadap Niat Belu Ulang Konsumen. Skripsi. Fakultas Ekonomi. Universitas Katolik Parahyangan.

Djoko Pekik Irianto. (2002). Dasar Kepelatihan. Jogjakarta: FIK. UNY.

Ghozali, Imam, (2018), Aplikasi Analisis Multivariate dengan Program IBM SPSS 25, Badan Penerbit Universitas Diponegoro, Semarang.

Hetanto, Eko, (2017), Kuesioner Kualitas Pelayanan Model SERVQUAL, Diakses: 4 Oktober 2018

Kurnianto, Ady NK. 2013. Kesiapan Profesi Personal Trainer dalam Penyusunan Program Latihan dan Jasa Layanan yang diberikan pada Members Fitness di Yogyakarta. Thesis. FIK UNY.

Kusumasari, Debbi Widya. 2013. Analisis Pengaruh Motivasi, Lokasi, dan Kualitas Layanan terhadap Keputusan Pemilihan Tempat Melatih Kebugaran Tubuh (Studi Kasus Pada Oryza Gym Fitness Center Semarang). Skripsi. Fakultas Ekonomika dan Bisnis. Universitas Diponegoro. Semarang. 
Noeraini, I. A., \& Sugiyono, S. (2016). Pengaruh Tingkat Kepercayaan, Kualitas Pelayanan, Dan Hargaterhadap Kepuasan Pelanggan Jne Surabaya. Jurnal Ilmu Dan Riset Manajemen (Jirm), 5(5).

Rakhmat, D. R. (2016). Karakteristik Dye-Sensitized Solar Cell (Dssc) Berbasis Zat Pewarna Alami Dari Ekstrak Jantung Pisang. Universitas Andalas.

Sugiyono, F. X. (2017). Instrumen Pengendalian Moneter: Operasi Pasar Terbuka (Vol. 10). Pusat Pendidikan Dan Studi Kebanksentralan (PPSK) Bank Indonesia.

Tjiptono, F., \& Chandra, G. (2005). Manajemen kualitas jasa. Yogyakarta: Andi.

Yuliani, S. H. (2005). Formulasi gel repelan minyak atsiri tanaman akar wangi (Vetivera zizanioidesi (L) Nogh): Optimasi komposisi carbopol 3\%. b/v.-propilenglikol. Indonesian Journal of Pharmacy, 16, 197-203. 